\title{
Factors Affecting the Development of Mathematical Knowledge for Teaching and Mathematical Beliefs of Prospective Primary Teachers
}

\author{
Ifada Novikasari a \\ a IAIN Purwokerto, INDONESIA
}

\begin{abstract}
This study aimed to obtain a description of the factors that influenced the knowledge development of teaching mathematics and mathematical beliefs owned by the students of prospective primary school teacher. The subjects of this study were 69 students of prospective primary school teacher in the second year that joined with the course of mathematics learning. The method used was quantitative descriptive method in which data collection techniques used tests, questionnaires and interviews. The results showed that the students of prospective primary school teacher had several factors that affected the test results of the mathematical knowledge for teaching and mathematical beliefs they had. The type of the highest mathematical beliefs, i.e. constructivist, began to emerge in two prospective primary school teachers who had the test results of the knowledge of teaching mathematics in the high category, with an educational background of vocational school and high school in social studies field.
\end{abstract}

KEYWORDS

factors, mathematical knowledge for teaching, mathematical beliefs, prospective primary teachers
ARTICLE HISTORY

Received 19 January 2017

Revised 25 April 2017

Accepted 29 April 2017

\section{Introduction}

Educational challenges in shaping the next pious and smart Indonesian generations are not only the responsibility of the government as the policy maker but also the responsibility of the teachers who teach them at school. Form of the current policy conducted by the government is educational curriculum reform, namely 2013 curriculum that has been controversial. Therefore, a lot of educational professionals, especially teachers, respond it because the change is too fast and lack of preparation (Novikasari, 2013). The dramatic effort to reform the curriculum, according to Corcoran (1995), improves expectation for students,

CORRESPONDENCE Ifada Novikasari $\square$ ifa_da@yahoo.com

(1) 2017 Novikasari. Open Access terms of the Creative Commons Attribution 4.0 International License (http://creativecommons.org/licenses/by/4.0/) apply. The license permits unrestricted use, distribution, and reproduction in any medium, on the condition that users give exact credit to the original author(s) and the source, provide a link to the Creative Commons license, and indicate if they made any changes. 
and consequently for teachers. Teachers are required to master new skills and responsibilities as well as changes in practice.

One of the reforms of the teaching profession has been stated in Act No. 14 Year 2005 Subsection 8 that:

Teachers are required to have academic qualification, competence, teaching certificate, to be physically and mentally healthy, and have the ability to achieve national education goals.

The statement above implies that it is important for teachers to have educational qualifications of teacher as a requirement for teaching. Teachers who already have an undergraduate qualification education have been assumed to have the experience and knowledge required in line with their profession. Teacher education institution can be the first step for every citizen who is eager to work as teacher. The provision of teacher candidates becomes their competence when they become teachers as regulated in Act No. 14 Year 2005 Subsection 10 concerning the competence of teachers that includes pedagogical, professional, personal, and social competences.

It is interesting to study the competence of teachers in teacher education. It is stated in the Minister of National Education of the Republic of Indonesia Number 16 of 2007 on Academic Qualification Standards and Teachers' Competency. Based on the regulation, teacher candidates have to achieve qualification as a teacher of primary school and have to master all primary school subjects.

Primary-school teacher education programs in several countries prepare prospective teachers for the basic level of classroom teachers and others became teachers with particular competence in accordance with their interests, for example in Finland which is famous for the best education system in the world. Primary school teacher preparation program is designed for teachers in low grade and high grade. Lower-grade teachers teach all subjects, while uppergrade teachers teach certain subjects, as stated in the following statement, primary school teachers major in education, while upper-grade teachers concentrate their studies in a particular subject (Shalberg, 2011, pp.14). Singapore, which is one of the best top five education systems in the world, provide primary school teacher preparation program for prospective teachers with a deep mastery of one content and mastery of the four subjects, as stated in the following:

... even for elementary teachers, a deep mastery of one content area plus preparation for the four major subjects they must teach (English language, mathematics, science, and social studies) (Choo \& DarlingHammond, 2011, p.35).

The curriculum that dominates in teacher education institutions relies on a policy set in each country to prepare its human resources to be a teacher. According to Ball (2000) it is important in teacher education to integrate the content knowledge and pedagogical knowledge as a provision for prospective 
teachers to face the real challenge as a teacher. The combination of knowledge will be able to improve the knowledge of teaching prospective teachers simultaneously (Welder \& Simonsen, 2011).

Development of study on recent content knowledge and pedagogical content knowledge has been specializing in mathematical material. The specificity is due to the complexity of knowledge that needs to be owned by teachers when teaching mathematics. According to Schoenfeld and Kilpatrick (2005) teaching mathematics requires specific knowledge. Such knowledge expects teachers not only simply master the content and be able to teach, but also need to have knowledge about the effectiveness of such representations of concepts in learning, an unusual strategy in solving mathematical problems, to understand students' thinking, etc. This is supported by a study conducted by Ball, Hill, and Bass (2005) and Tatto, Schwille, Senk, Ingvarson, Peck, and Rowley (2008) that mathematical knowledge for teaching (MKT), which consists of mathematical content knowledge (MCK) and mathemtical pedagogic content knowledge (MPCK) owned by teachers is an important factor for the success of students' mathematics at school.

A philosophical view on the role of teachers in the learning oriented to the result divides into three types of teachers. First, teachers, as the instructors, emphasize on the mastery of expected skills. Second, teachers, as the explainers, have orientation on the conceptual understanding with intact knowledge. Third, the facilitators have confidence in problem posing and solving. According to Ernest (1989) the role of teachers as the instructors representing instrumentalist philosophy are the lowest level, teachers as explanatory represent platonic philosophy, and teachers as facilitators representing a philosophical view about solving the problem are the highest level of the role of teachers. However, the growth of teachers' role is influenced by beliefs, social context, and the level of thinking. If beliefs can be determined and the social context is a choice, then the key factor is in the level of thinking. The higher the level thinking is, such as self-evaluation, the more beliefs will be encouraged $o$ use in one's practice.

The success of prospective teacher students which is expected to develop MKT that results in the changes in mathematical beliefs is not only influenced by the existing curriculum in teacher education program. Based on the study of factors affecting the acquisition of knowledge in teacher education program, social and economic factors including the educational background of parents (Noble , et al ., 2006) , the material support (Okioga , 2013), and social relationships (Mushtaq \& Khan, 2012) have an effect on it. In addition, factors that influence the development of mathematical beliefs among prospective teachers are secondary school educational background (Somayajulu, 2012) and motivation to study in the teacher education program (Topkaya \& Uztosun, 2012). This study aims to examine the factors that influence the acquisition of knowledge of teaching Mathematics and mathematical beliefs of prospective primary school teacher students.

\section{Literature Review}




\section{Mathematical Knowledge for Teaching (MKT) and Mathematical Beliefs (MB)}

Knowledge of KTM type according to Ball, et al. (2008, p. 395) is "mathematics knowledge that teachers need to carry out their work as teachers of mathematics." This mathematical knowledge is used by teachers in the classroom to make teaching and development of students (Hill, et al., 2008) so that the definition of MKT is found in the terms of work that teachers do. This knowledge has a 'speciality' of mathematics, because not only is the teacher limited to explain if it is true or false, but also can diagnose the fault of students and provide proper guidance (Ball \& Bass, 2009). The task of teaching can be developed with MKT, so according to Powell and Hanna (2006) MKT is a kind of knowledge that is applied in a specific context to help students develop ideas and mathematical reasoning.

Knowledge of teaching mathematics is divided into two kinds of knowledge, namely MCK and MPCK. Referring to Ball, et al. (2008) and Tatto, et al. (2008) MCK indicators are the ability to provide definition in mathematics and calculating procedural; represent mathematical ideas precisely; and connect interrelated mathematical ideas. Here are examples of application of MCK in mathematical learning (Ball, et al., 2008),

1. The ability to provide definition in mathematics and calculating procedural.

Teachers have basic knowledge about 307-168 reduction. Suppose, knowledge about the value of a $307=3$ hundreds +7 unit, and $168=1$ hundred +6 tens +8 unit so that the next step knowledge of place value can be connected with the reduction strategy. Teachers need to know the reduction algorithms commonly done, namely

$$
\begin{array}{lll}
3 & 0 & 7 \\
1 & 6 & 8 \\
\hline 1 & 3 & 9
\end{array}-
$$

2. The ability to represent mathematical ideas precisely.

Continuing from the example above, teachers need to know other ways to complete calculating the reduction, among others:



3. The ability to connect interrelated mathematical ideas.

Students make an error in calculating the reduction, such as

$$
\begin{array}{lll}
3 & 0 & 7 \\
1 & 6 & 8 \\
\hline 2 & 6 & 1
\end{array}-
$$


Teachers can declare that 261 is an inappropriate answer. However, teachers who can only see that the answer is false do not complete themselves well to help students learn correctly. Teaching skill needs teachers who can measure the source of a mathematical error. For example, the students' error in the calculation of each column represents the difference between the two-digits or digit reduction which is smaller than the larger one.

Indicators in MPCK include the ability to create a variety of representations for the purpose of interpreting, understanding the structure and the interrelationship in mathematical topics, and anticipating students' thought on misconceptions. Here is an example of application MPCK teachers (Ball, et al., 2008) in learning. Suppose teachers need to design their teaching before handing off the task completion of the operation subtraction 307-168. They determine the order of teaching materials from the beginning and give examples so that students have the depth of the material. They also need to evaluate the benefits and disadvantages representation used to teach a particular idea. Each of these steps requires interaction between specific mathematical understanding and pedagogical issues understanding that affect students' learning, based on students' common errors usually done, such as the following reduction:

$$
\begin{array}{llll}
3 & 0 & 7 & \\
1 & 6 & 8 & - \\
\hline 2 & 6 & 1
\end{array}
$$

It becomes a very common error for students and teachers are accustomed to such an error done by the students. Therefore, knowledge based on the type of error comes from experience with the students and their thinking knowledge. Such knowledge is one that combines the knowledge of students and mathematics. In addition, the reduction material needs to be related with other materials in the curriculum and textbooks.

Efforts in developing MKT are supposed to influence the change of mathematical beliefs of prospective teachers. The study results of Raymond (1997), Ambrose (2004), and Luft and Rehrig (2007) show that the process of lecturing Mathematics intended to develop MKT of the prospective mathematics teachers causes change in their MB.

The conviction itself uses the term beliefs. Beliefs is defined by Philipp (2007, p. 258 ) as the lenses through which an individual looks when interpreting the world and as such affects the way one interacts with the world. Beliefs, according to Torner and Pehkonen (1999), is a combination of diverse conclusions about the phenomenon and its naturalness from its own experience and the initial perception that exists in the surroundings. If beliefs is associated with Mathematics, it is so-called mathematical beliefs (MB). According to Underhill (Leder, et al., 2002) beliefs in mathematics is the summary of four beliefs, namely (i) beliefs in Mathematics as a discipline, (ii) beliefs in learning Mathematics, (iii) beliefs in teaching Mathematics, and (iv) beliefs in one self in the context where Mathematics learning occurs.

Mathematical Beliefs, according to Ernest (1989), comes from three philosophies, namely instrumentalist, platonic, and constructivist. 
Instrumentalists view mathematics as a collection of facts, rules, and skills used to reach the final objective. This Mathematics is a set of helpful rules and facts, but is not interrelated. Platonists view Mathematics as static knowledge; it is however the unity of intact knowledge. Mathematics, as knowledge, is invented, not created. The third view is constructivists. They consider that Mathematics is dynamic and can extend continuously from creation and invention. Mathematics is the process of investigating and finding out, not the final outcome, and the result is open to improvement. The following categories of mathematical beliefs are formulated by Mosvold and Fauskanger (2013).

Tabel 1 Extension of Beswick's Categories of Teachers' Beliefs

\begin{tabular}{l|llc}
\hline $\begin{array}{c}\text { Beliefs about the } \\
\text { nature of } \\
\text { mathematics }\end{array}$ & $\begin{array}{c}\text { Beliefs about } \\
\text { mathematics teaching }\end{array}$ & $\begin{array}{c}\text { Beliefs about } \\
\text { mathematics } \\
\text { learning }\end{array}$ & Beliefs about \\
\hline Instrumentalist & Content for performance & Mastery of skills & $\begin{array}{c}\text { Remembering } \\
\text { content }\end{array}$ \\
Platonist & $\begin{array}{l}\text { Content with } \\
\text { understanding }\end{array}$ & $\begin{array}{l}\text { Construction of } \\
\text { understanding }\end{array}$ & $\begin{array}{l}\text { Understanding } \\
\text { content }\end{array}$ \\
Problem Solving & Learner focused & $\begin{array}{l}\text { Autonomous } \\
\text { exploration }\end{array}$ & $\begin{array}{l}\text { Adjusting and } \\
\text { differentiating }\end{array}$ \\
\hline
\end{tabular}

Source: Mosvold and Fauskanger (2013)

Prospective teachers with MB instrumentalist believe that Mathematics is a set of rules, formulas and mathematical knowledge that are not interrelated; the purpose of teaching Mathematics is for students to master the rules and the formula. Referring to Schmidt and Kennedy (1990) that one's beliefs can affect not only the pedagogic selection but also the content selection, MB prospective teachers can be identified from the results of test. The type of this beliefs has two tendencies, namely the tendency of prospective teachers who are lack of content knowledge and the tendency of prospective teachers who master content knowledge. If the type of prospective teachers' beliefs improves with beliefs that students need to understand mathematical content, they use representation to explain mathematical content. The prospective teachers are so-called to have platonic mathematical beliefs. The knowledge of the type of the beliefs has developed in representing interrelated mathematical ideas to provide understanding. The highest MB level is constructivist. In this level, prospective teachers believe that Mathematics can develop creations done independently by students. Thus, prospective teachers with the type of this beliefs have been able to relate the ideas of students with mathematical ideas which keep on growing and able to give a proper response in anticipating of students' thinking.

The framework of TEDS-M (Tatto, et al., 2008) states that beliefs significantly affects teaching and it is the intrinsic characteristics of people to be teachers. The beliefs scale of TEDS-M includes five fields, namely beliefs about the nature of Mathematics, the study of Mathematics, the achievement of Mathematics, the readiness to teach Mathematics, and the effectiveness of program. 
Based on Underhill's categorization in Leder, et al. (2002), McLeod (1992), and Tatto, et al. (2008) about the beliefs in mathematics education, the researcher interprets that the dimensions of prospective teachers in mathematics education are beliefs about Mathematics, beliefs about learning, and beliefs about teaching mathematics by means of factors that describe such beliefs, namely instrumentalists, platonists, and problem solving or constructivists.

\section{Factors Affecting the Development of MKT and MB}

Mastery of knowledge in studying mathematics for the majority of prospective teachers becomes educational success indexes in the program. Students' success in education relating to the acquisition of knowledge, according to Okioga (2013) is influenced by socio-economic background. It may be material support to fulfill the needs of study, such as books, food quality, and study materials. Parents of students with less economic background will pay less attention and give less support to their children's activity. On the other hand, parents with their high economic background often use discussion approach to regulate their children's activity so that it is more advantageous for the children with middle to high economic circumstances because parents' attention and attitude are positive. Study of Demir, Kilic, and Unal (2010) finds that the educational background of parents is an important indicator for the success of mathematical education of children. The higher the parents' education is, the more successful their children's Mathematics is.

Socio-economic background above is identified by Bornstein and Bradley (2003) as the socio-economic status. Socio-economic status is defined as the position of individual, family, or group within the social strata system based on social values such as work, education, economic resources, power, and a variety of knowledge in the society. The complicated process of social stratification will hierarchically group the society to lead them to access based on that value. General view of the social economic status pushes for an investigation into the socio-economic status, parenting and children development.

Related to the development of children in education, Mushtaq and Khan (2012) state that the success of children in school can be affected by the ability of communication, learning, good guidance, and the presence or absence of pressure at home. In line with this Noble, et al. (2006) also report that the parents' income, education level, and the negative situation at home is not a direct effect on students' success. Parents with higher education demand their children to succeed because they believe that education can be the path to success. Study on the different result is obtained by Guo and Harris (2000), which indicates that the parents' status has a significant influence on the success of mathematics only in early childhood. The effect does not show continuity after formal education. By reason of important period in a children's life when developing cognitive abilities before attending formal education still has the greatest influence of parents, the much higher educational background of the parents is used before children enter formal education.

Based on the description above, the researcher formulates that the factors that influence the knowledge development of teaching Mathematics of prospective 
teachers are parents' education, material support, and social relationship. Teacher educators sometimes in assessing prospective teachers only pay attention to cognitive aspects, but do not pay attention to the level of prospective teachers' beliefs. Even the educators assume that the cognitive aspects and the level of prospective teachers' beliefs are the same. Although the model or schema between knowledge and beliefs, according to one's opinion, is psychologically a unity, but according Eynde, et al. (2002) they are different. According Topkaya and Uztosun (2012) prospective teachers will be more successful in their education if they have positive motivation on their role in the future, such as liking children, teaching with the aim to develop children's knowledge. Besides, the educational background of prospective teachers is supposed to influence mathematical beliefs they have. Since, according to Philipp (2007), the way people gain beliefs from previous educational affects on the beliefs they have so that factors which are supposed to affect mathematical beliefs of prospective teachers are previous education and motivation in studying in primary-school teacher education program.

\section{Method}

The method used is descriptive quantitative method. This research was conducted in a State Institute at primary teacher education program in Indonesia. The research subject was the fourth semester students who had followed the course of Numbers and Geometry with a total of 69 prospective teacher students. The study was conducted for three months, i.e. from April to June. The instruments used in the study were MKT tests and questionnaires. MKT tests contained MCK test and MPCK test, which was developed from Ma (1999) and Cheang, et al. (2007), and had been consulted with experts and tested. The results of MCK test showed reliability of 0.619 and validity of 0.57 . The results of MPCK test showed the reliability of 0.641 and the validity of 0.54 . Then, based on the test results of MCK and MPCK, prospective teachers are categorically grouped by average and standard deviation (Arikunto, 2005). Thus, it was obtained MCK and MPCK groups of prospective teachers containing low, medium, and high categories.

Structured interview used was test-based interview to identify the type mathematical content of prospective teachers. According Sudjana (2005: 69) a structured interview is conducted to determine the specific aspects of the respondents to the question that has been drawn up clearly. The questionnaires were arranged based on the study of the factors which are supposed to influence the MKT and MB they had. Unstructured interview which was the follow-up interviews was used to determine the experience during interacting with the mathematical science.

\section{Results}

\section{Result of the MKT}

Mathematical content knowledge as measured in this study was limited to procedural computing capabilities, defining concept, representing mathematical ideas, and linking among mathematical ideas. Data MCK of prospective teacher 
students are measured through test description that has been developed based on the number of 6 questions. In addition, the MPCK as measured in this study was limited to the ability to produce different representations / methods / mathematical procedures for the purpose of explaining, understanding the structure and interrelatedness in mathematical topics, and the ability to anticipate the students' thinking of misconceptions. The MPCK of prospective teacher students was measured through essay test with 7 questions. Here was the result of tests that had been given.

Table 2 Number of Students by Category of Test Results of MCK and MPCK

\begin{tabular}{lccc}
\hline \multirow{2}{*}{ MKT } & \multicolumn{3}{c}{ Category } \\
\cline { 2 - 4 } & Low & Medium & High \\
\hline MCK & 13 & 45 & 11 \\
MPCK & 13 & 43 & 13 \\
\hline
\end{tabular}

Table 2 showed that the number of students in a category MCK and MPCK spread in the category of high, medium, and low with MCK and MPCK in the same category that had nearly the same amount.

\section{Result of the Research on $M B$}

The beliefs was obtained from questions adapted from Cheang, et al. (2007), namely question:

If you are in a situation to teach the area of a rectangle to the students that will be newly given the material, how do you explain the concept of a rectangular area to the students?

Various answers were given by prospective teachers, but in general the whole prospective teacher students answered with a tendency as follows:

Table 3 Identification of MB of Prospective Primary Teachers

\begin{tabular}{|c|c|}
\hline Types of Answers of Prospective Teachers & Tendency of MB \\
\hline $\begin{array}{l}\text { Area of the rectangle is } \mathrm{L}=\text { length } \mathrm{x} \text { width, If we let length } \\
=3 \mathrm{~cm} \text { and width }=2 \mathrm{~cm} \text {, the area is } \mathrm{L}=3 \mathrm{~cm} \times 2 \mathrm{~cm}=6 \\
\mathrm{~cm} 2\end{array}$ & $\begin{array}{l}\text { Prospective teachers are } \\
\text { identified as having } \\
\text { instrumentalist } \mathrm{MB}\end{array}$ \\
\hline $\begin{array}{l}\text { Area of a rectangle can be known by making representation } \\
\text { of rectangle shape. } \\
\text { The area is the value of the area covered by the margins. } \\
\text { The number of small square indicates the value of the area, } \\
\text { that is } 6 \text {. So, the area of the rectangle is length } \mathrm{x} \text { width, so } \\
\text { that } 3 \mathrm{~cm} \times 2 \mathrm{~cm}=6 \mathrm{~cm} 2\end{array}$ & $\begin{array}{l}\text { Prospective teachers are } \\
\text { identified as having } \\
\text { Platonist MB }\end{array}$ \\
\hline $\begin{array}{l}\text { The answer was similar to the type of platonist, but the } \\
\text { prospective teachers provided the formula of area in the } \\
\text { final explanation. The number of swathe in the figure was } 6 \text {, } \\
\text { then } 6 \text { could be obtained from } 3 \times 2 \text {, so that the formula of } \\
\text { area was obtained from length x width. }\end{array}$ & $\begin{array}{l}\text { prospective teachers have } \\
\text { constructivist/problem } \\
\text { solving MB }\end{array}$ \\
\hline
\end{tabular}


The followings were the final results on the test-based interview to prospective teachers.

Table 4 Number of Students based on MB

\begin{tabular}{ll}
\hline Mathematical beliefs & Amount \\
\hline Instrumentalist & 57 \\
Platonist & 10 \\
Constructivist & 2 \\
\hline
\end{tabular}

Table 4 showed that the majority of prospective teacher students had instrumentalist mathematical beliefs. The beliefs of constructivist type only had two prospective teacher students.

\section{Factors Affecting the Development of MKT}

a. Factor of Parents' Education

Parents are the first educators for children. Their role is very significant in children's development. The higher the parents' education and experiences for education are, the more they will understand the importance of education to support children's success in the future. Their guidance in educating children is influenced by the maturity of thinking. Parents' education factor will affect the success of their children in education.

Based on Table 1 prospective teachers with categories MCK test results and high MPCK are influenced by their father with an educational background S1 / Diploma, high school / junior high schools, and others. They were also supported by their mother's educational background of S1 / Diploma, high school / junior high schools, and others. Overall, the most category in the category of test results MCK and MPCK had father-and-mother educational background of Senior High School / Junior High School, and then followed others. Educational backgrounds that belonged to other qualifications were those who just graduated from Primary School, did not graduate education, or did not study at school at all.

Table 5 Percentage of Prospective Teachers by MCK and MPCK Categories and Factor of Parents' Education

\begin{tabular}{llcccccc}
\hline \multirow{2}{*}{ Category } & \multicolumn{3}{c}{ MCK } & \multicolumn{3}{c}{ MPCK } \\
\cline { 3 - 8 } & & Low & Medium & High & Low & Medium & High \\
\hline $\begin{array}{l}\text { Father's } \\
\text { Education }\end{array}$ & Master/Doctoral & 0 & 1.01 & 0 & 0 & 1.01 & 0 \\
& $\begin{array}{l}\text { Bachelor/Associate's } \\
\text { Degree }\end{array}$ & 1.01 & 8.08 & 0 & 1.01 & 7.07 & 1.01
\end{tabular}




\begin{tabular}{llcccccc}
\hline & Secondary School & 8.08 & 36.36 & 6.06 & 5.05 & 42.42 & 3.03 \\
& Others. & 9.09 & 26.26 & 4.04 & 4.04 & 28.28 & 7.07 \\
Total & & 18.18 & 71.72 & 10.1 & 10.1 & 78.79 & 11.11 \\
$\begin{array}{l}\text { Mother's } \\
\text { Education }\end{array}$ & Bachelor/Associate's & 1.01 & 11.11 & 0 & 1.01 & 1.01 & 1.01 \\
& Degree & & & & & & \\
& Secondary School & 9.09 & 36.36 & 7.07 & 6.06 & 41.41 & 5.05 \\
& Others & 8.08 & 24.24 & 3.03 & 3.03 & 27.27 & 5.05 \\
\hline Total & & 18.18 & 71.71 & 10.1 & 10.1 & 78.79 & 11.11 \\
\hline
\end{tabular}

Table 5 showed that parents' educational background did not guarantee their children at the high category for test results of MCK and MPCK. On the contrary, lower parents' education did not make their children in the lower category.

\section{b. Factor of Material Support}

This factor would identify the parents' job and allowance of prospective teachers in one week. Parents' job showed the parents' ability to provide material support through earned income. The factor may have influenced the success of the MCK and MPCK tests of prospective teachers with supplies that could fulfill the needs during their study in teacher education. The category of prospective teachers' allowance was adjusted to the living cost in Central Java. Sufficient support materials could meet the nutritional food, the need of book, education access, and so on.

Table 6 Percentage of the Number of Prospective Teachers Based on MCK and MPCK Categories and Support Materials Factor

\begin{tabular}{llcccccc}
\hline & Category & \multicolumn{3}{c}{ MCK } & \multicolumn{3}{c}{ MPCK } \\
\cline { 3 - 8 } & & Low & Medium & High & Low & Medium & High \\
\hline $\begin{array}{l}\text { Parents' } \\
\text { Job }\end{array}$ & Civil Servant & 1.01 & 9.09 & 1.01 & 2.02 & 8.08 & 1.01 \\
& Soldier / Police & 0 & 1.01 & 0 & 0 & 1.01 & 0 \\
& Entrepreneur & 5.05 & 16.16 & 3.03 & 2.02 & 19.19 & 3.03 \\
& Farmer & 5.05 & 25.25 & 4.04 & 2.02 & 28.28 & 4.04 \\
& Others & 7.07 & 20.20 & 2.02 & 4.04 & 22.22 & 3.03 \\
Total & & 18.18 & 71.72 & 10.1 & 10.1 & 78.79 & 11.11 \\
$\begin{array}{l}\text { Allowance } \\
\text { for a } \\
\text { week }\end{array}$ & IDR 150,000 & 0 & 4.04 & 1.01 & 0 & 5.05 & 0 \\
& IDR 50,000 - IDR & 13.13 & 57.58 & 9.09 & 10.1 & 60.61 & 9.09 \\
& 150,000 & & & & & &
\end{tabular}




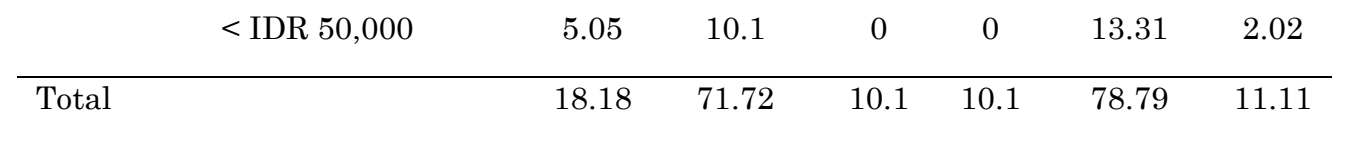

Table 6 showed that prospective teachers at the high category in MCK and MPCK backgrounds varied in parents' job, such as civil servant, entrepreneur, farmer, and others. With the background of parents' job, the majority of prospective teachers who had high-categorized test results of MCK and MPCK received allowance more than IDR 150,000 and between IDR 50,000 until IDR 150,000 for one week. Even, it was found that prospective teachers with highcategorized test results of MPCK received allowance less than IDR 50,000for one week.

The high-categorized and medium-categorized test results of MCK and MPCK were prospective teachers who mostly had parents working as farmers with allowance between IDR 50,000 until IDR 150,000. Based on the description above, it appeared that the material support did not guarantee the prospective teachers to have high-categorized test results of MCK and MPCK.

\section{c. Factor of Social Relationship}

Factor of social relationship may have influenced the test results of MCK and MPCK of prospective teachers. The factor included their home stay during their study and extracurricular activities. The home stay during their study was differentiated among parents' house, boarding house, Islamic boarding house, and their relative's house indicating independence and relationship with others. Extracurricular activities followed by them were able to develop prospective teachers' communication skills and may have influenced success in the study.

Table 7 Percentage of the Number of Prospective Teachers based on MCK and MPCK Categories and Social Relationship Factor

\begin{tabular}{llcccccc}
\hline \multirow{2}{*}{ Category } & \multicolumn{3}{c}{ MCK } & \multicolumn{3}{c}{ MPCK } \\
\cline { 2 - 7 } & & Low & Medium & High & Low & Medium & High \\
\hline $\begin{array}{l}\text { Home stay } \\
\text { during study }\end{array}$ & Parents' House & 10.1 & 21.21 & 3.03 & 2.02 & 30.3 & 2.02 \\
& Boarding House & 0 & 17.17 & 2.02 & 1.01 & 15.15 & 3.03 \\
& Islamic & 8.08 & 28.28 & 5.05 & 7.07 & 29.29 & 5.05 \\
& Boarding House & & & & & & \\
& Relative's & 0 & 5.05 & 0 & 0 & 4.04 & 1.01 \\
Total & House & 18.18 & 71.72 & 10.1 & 10.1 & 78.79 & 11.11 \\
$\begin{array}{l}\text { Extracurricular } \\
\text { activities }\end{array}$ & Scouting & 3.03 & 16.16 & 2.02 & 2.02 & 18.18 & 1.01 \\
& Student & 3.03 & 3.03 & 1.01 & 1.01 & 5.05 & 1.01 \\
\hline & Executive Board & & & & & &
\end{tabular}




\begin{tabular}{lcccccc}
$\begin{array}{l}\text { Muhammadiyah } \\
\text { Students } \\
\text { Association }\end{array}$ & 0 & 2.02 & 0 & 0 & 2.02 & 0 \\
& & & & & & \\
Teaching & 1.01 & 6.06 & 0 & 0 & 6.06 & 1.01 \\
Others & 1.11 & 44.44 & 7.07 & 7.07 & 47.47 & 8.08 \\
\hline & 18.18 & 71.71 & 10.1 & 10.1 & 78.78 & 11.11
\end{tabular}

Table 7 showed that highest-categorized test results of MCK and MPCK happened to prospective teachers who lived in Islamic boarding school with a choice of 'other' extracurricular activities during their study. Selection of 'other' could be meant that there were notextracurricular activities or those who lived in Islamic boarding school joined with the activities in their Islamic boarding school. The highest-categorized test results of MCK were owned by prospective teachers who lived at home and Islamic boarding school with the activities of 'others' and scouting/ Student Executive Board. The highest-categorized test results of MPCK were owned by prospective teachers who lived in Islamic boarding school and had the activities of 'others'. The obtained results showed that the test results of MCK and MPCK were not much different between medium and high categories and that by living in Islamic boarding school and choosing activities of 'others' would dominate the categories. Based on this description above, it appeared that prospective teachers with activities mostly in Islamic boarding school had the results of MCK and MPCK spreading from low to high categories. This could be implied that social relationship had no influence on the test results of MCK and MPCK.

\section{Factors Affecting the Development of MB}

\section{a. Factor of Secondary School Education Backgrounds}

This factor described the building of prospective teachers' mathematical beliefs with various secondary school education backgrounds. Prospective teachers with different use of Mathematics in secondary school may have affected their views of mathematics, learning Mathematics, and teaching Mathematics. Habit in secondary school shaped different experience when prospective teachers interacted with mathematics, and when they met mathematics course that would be taught in primary school, they would study it in accordance with their mathematical beliefs.

Table 8 Percentage of Prospective Teachers Based on MB and Factors of Secondary School Background

\begin{tabular}{llccc}
\hline \multirow{2}{*}{ Category } & \multicolumn{2}{c}{ MB } \\
\cline { 3 - 4 } & & Instrumentalist & Platonist & Constructivist \\
\hline Educational & Senior & 24.24 & 8.08 & 0 \\
Background of & High & & \\
Secondary School & School & & \\
& & & \\
\end{tabular}




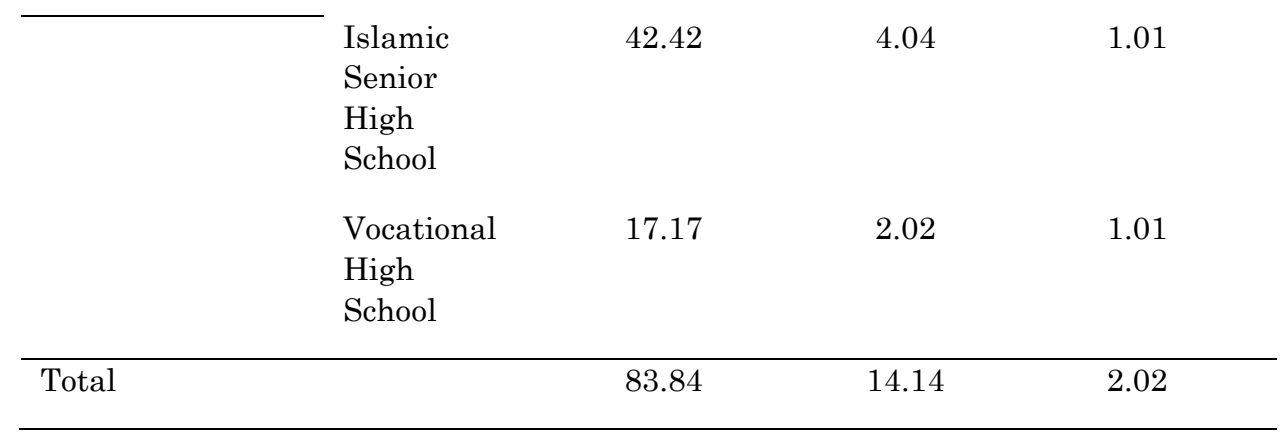

Table 8 above showed that prospective teachers with Islamic High School and Vocational High School backgrounds had constructivist mathematical beliefs. Furthermore, prospective teachers with Senior High School, Islamic High School, and Vocational High School had platonist mathematical beliefs, with the largest number of Senior High School graduates. The background of instrumentalist-categorized prospective teachers was dominated by those who had Islamic High School background, then followed by Senior High School and Vocational High School. The description above indicated that the background of secondary schools did not put any prospective teachers on constructivist mathematical beliefs. It could be inferred that the background of secondary school education affected the formation of several prospective teachers' mathematical beliefs.

\section{b. Factor of Motivation to Study}

The motivation for choosing teacher education program that came from themselves would generate the passion to follow all existing courses. This factor may have affected the prospective teachers' MB to succeed in learning Mathematics.

Table 9 Percentage of the Number of Prospective Teachers Based on their MB and Factor of Motivation to Study

\begin{tabular}{|c|c|c|c|c|}
\hline \multirow{2}{*}{\multicolumn{2}{|c|}{ Category }} & \multicolumn{3}{|c|}{ MB } \\
\hline & & Instrumentalist & Platonist & Constructivist \\
\hline \multirow{4}{*}{$\begin{array}{l}\text { Sources of } \\
\text { motivation to } \\
\text { study in Islamic } \\
\text { Primary School }\end{array}$} & Themselves & 42.42 & 5.05 & 1.01 \\
\hline & Parents & 29.29 & 6.06 & 0 \\
\hline & Relatives & 8.08 & 2.02 & 1.01 \\
\hline & Others & 4.04 & 1.01 & 0 \\
\hline \multicolumn{2}{|l|}{ Total } & 83.83 & 14.14 & 2.02 \\
\hline $\begin{array}{l}\text { Feelings to study } \\
\text { in Islamic }\end{array}$ & Happy & 62.63 & 13.13 & 2.02 \\
\hline \multirow[t]{2}{*}{ Primary School } & Ordinary & 21.21 & 1.01 & 0 \\
\hline & Unhappy & 0 & 0 & 0 \\
\hline
\end{tabular}




\begin{tabular}{lccc}
\hline Total & 83.84 & 14.14 & 2.02 \\
\hline
\end{tabular}

In Table 9, it appeared that constructivist MB was owned by prospective teachers who had motivator resources from themselves and relatives. Prospective teachers, after attending courses in teacher education of Islamic Primary School, were happy with the existing programs. In Platonist MB, the highest motivator's position came from parents, and then followed by themselves, relatives, and others. The indication of affective side was in the form of feeling happy and ordinary during the teacher education program. Then, the highest motivator resources of instrumentalist MB were themselves, followed by parents, relatives, and others. Prospective teachers in instrumentalist MB felt happy and only a few chose 'ordinary' during the study. The results showed that most of the prospective teachers were motivated by themselves and felt happy to study in teacher education program, although some prospective teachers felt 'ordinary' during the study.

The results of the factor analysis that may have affected MB were, among others, the factors of secondary school educational background and motivation to study. The distribution of motivation to study showed that there was no difference among instrumentalist, platonist, and constructivist MB of prospective teachers. However, the factor of secondary school education background was not found in prospective teachers with constructivist MB that had Senior High School background. It may have been affected by the way of their learning in Senior High School.

\section{Discussion}

\section{MKT and MB}

The knowledge of prospective teachers which was in the form of MCK and MPCK test results were categorized in lower, medium, and high categories. The tendency of prospective teachers in the lower category was the ability of problem identification and procedural arithmetic. Medium-categorized prospective teacher students were able to solve various questions, but they were poor to make mathematical ideas connections and to respond questions. Highcategorized prospective teachers tended to master the mathematical content and were able to give proper responses on the given questions. The given questions were mathematical learning problem-based questions. According to Fennema and Franke (in Petrou \& Golding, 2001) the essential of effective mathematics teaching is knowledge about how students think and learn Mathematics.

The results of research on MKT showed that the most number of prospective teacher students were in the medium category. This contrasted with the results obtained through test-based interview on prospective teachers about their mathematical beliefs. It showed that the most were in instrumentalist MB. Referring to McLeod and McLeod (2002), there was a close relationship between cognitive and beliefs so that prospective teacher students' MB could be traced by MKT test results. MKT test results showed that although the majority of students were in the medium category, some students had not been able to 
explain understanding-oriented mathematical content. Students still tended to explain through memorizing formula and procedural arithmetic, and were difficult to provide representation for the purpose of explaining. As the study of Ball (1990) prospective teachers whose knowledge was based on memory would be difficult to make representations of mathematical ideas and unable to explain the reasons why the selection of procedural arithmetic algorithm was done.

Questionnaire was instrument used to determine information regarding the factors that may have affected the MKT test results and the type ofprospective teachers' MB. Analysis of the questionnaire was grouped into five, namely the three factors in MKT and the two factors in MB.

\section{Factors Affecting the Development of MKT and MB}

Factors which may have affected MKT were, among others, parents' education, material support, and social relationship factors. Factors which may have affected MB were factors of secondary school educational background and motivation to study.

Factor of parents' education for prospective teachers was dominated by Senior High School/ Junior High School for prospective teachers with mediumcategorized and high-categorized MCK and MPCK. The master/doctoral degree and bachelor degree educational background of parents encouraged MCK and MPCK less to be in the high category. The average of prospective teachers was in the medium category. So, in the three research classes, parents' educational factor less affected the MCK and MPCK test results of prospective teachers. Although the educational background of the parents of prospective teachers was dominated by Senior High School/Junior High School, prospective teachers always joint the class and had MKT test results in high and medium categories.

Factor of parents' educational background had less influence on the outcome of MKT. The result was supported by study conducted by Bicer, Capraro, and Capraro (2013). It stated that the communication between parents and children had a great influence on their children's success during formal education, apart from factor of parent's expectations affected by educational background. Study conducted by Starkey and Klein (2000) specifically mentioned that the educational background of parents influenced on children's success, noting that the educational background supported the development of prospective teachers' mathematics, namely mathematics field. The research on parents' educational background showed that the prospective teachers had parents with S1 and S2/S3 backgrounds, but not in Mathematics. Therefore, it could be obtained on the analysis that though the prospective teachers had parents with Senior High School/Junior High School background, communication between parents and children ran well. Communication was established in the form of the expectations of parents on the success of prospective teachers in the teacher education program so that later they could become good primary school teachers.

The influence of support material category on the MKT test results did not seem any difference. Prospective teachers' allowance with lower, medium and high MCK and MPCK categories was in the range between IDR 50,000 and IDR 
150,000 per week. With the majority of the parents' job were farmers and the living cost was fairly cheap on campus, material support factor did not affect too much the MCK and MPCK test results of prospective teachers. Therefore, the similar material support prospective teachers had but different in the categories of KTM test results could be caused by other factors. Study conducted by Goldrick-Rab, Harris, and Trostel (2009) revealed that students' success at the university was based on the theory of human capital. When people got benefit from their study later, with the time and cost spent during their study, they would try to succeed in their study. Due to the limited theory, Goldrick-Rab, et al. (2009), stated that when reduction in tuition fees at universities happened, students tended to attend the class and finish their study. It was in line with the findings in this study. Material support was less influential on the success of students' MCK and MPCK tests because the tuition fee at the university the researcher conducted research was quite cheap compared with other universities in Central Java and the living cost was relatively inexpensive as well.

The test results of MCK and MPCK did not differ between medium-categorized prospective teachers and high-categorized prospective teachers, stating that by living in Islamic boarding school and choosing the activities of 'others' dominated the category. Aspect of 'others' was interpreted as not having extracurricular activities so that the choice of home stay during their study did not guarantee high results on PCMB and MCK. Research conducted by Wayt (2012) showed that persistence in study was influenced by positive relationships with family and friends. An academic friendship had little impact on the relationship. Living in Islamic boarding school gave a positive relationship in a non-academic friendship.

Factor of secondary school background towards MB prospective teachers was dominated by Islamic Secondary School graduates for instrumentalist, Platonist, and constructivist mathematical beliefs. This probably happened because most of the prospective teacher inputs came from Islamic High School. Minority category to which the vocational-graduate prospective teachers belonged managed to put Subject 1 on constructivist MB, and then followed by Subject 2 who graduated from Islamic High School majoring in Social Science. As the study result conducted by Somayajulu (2012), the secondary-school educational background of prospective teachers influenced the perspective on mathematics. Subject 1 coming from vocational high school looked at mathematics as the applied science so that it was necessary to teach it comprehensively and creatively towards real life. The mathematical beliefs was shaped from experience how s/he got that beliefs (in Philipp Thompson, 2007). Subject 1, through interview, shared his or her experience when he was in the vocational high schools he used mathematical when working in the engineering workshop. The experience of using Mathematics as an applied science and created in the engineering workshop indirectly caused Subject 1 to shape constructivist mathematical beliefs. But it was also possible for prospective teachers with Vocational High School background to be at instrumentalist MB if they had lower test results of MCK and MPCK. Schmidt and Kennedy (1990) stated that the beliefs that one had affected the pedagogical and content choices when explaining the particular context in Mathematics so that the test results MCK and MPCK proved prospective teachers' MB. 
Despite from Islamic High School majoring in Social Science, Subject 2 achieved high-categorized test results of MCK and MPCK. Subject 2 had the similar view with Subject 1on teaching Mathematics. Mathematics should have been created independently by students. Based on his or her experience in Islamic High Schools she liked Accounting so that she thought that mathematics was beneficial and developed in other sciences. As stated by Ernest (1989), social context affected e on the formation of one's MB. The social context that utilized Mathematics in Accounting supported the establishment of constructivist MB nature and developed in teacher education.

Type of platonist mathematical beliefs was traced through two prospective teachers, namely Subject 3 and Subject 4 who had Senior High School background majoring in Natural Science. The prospective teachers got the highcategorized test results of MCK and MPCK, but poor to make connections on mathematical ideas. It may have been caused by stressing on formulas but poor in application. As stated by Ball (1990), prospective teachers whose knowledge was based on the memory would be difficult to give a representation of mathematical ideas. Prospective teachers with instrumentalists MB type had been identified poor in Mathematics since they were in secondary school. According to studies conducted by Zerpa, Kajander, and van Barneveld (2009), students with poor procedural skills did not get a lot of benefits in the conceptual development during their study.

Factor of source of prospective teacher students' motivation studying in primaryschool teacher education program with instrumentalist, platonist, and constructivist MB spread on the category that came from themselves, parents, and relatives. Motivation less influenced the formation of prospective teachers' MB because, according to Thompson (Philipp, 2007), beliefs was a mental structure which was dynamic and may have changed because of experience. Therefore MB was influenced by experiences during joining mathematics learning or interacting with Mathematics, not influenced by motivation to study in primary-school teacher education program. Handal (2003) believed that it was difficult to change students' MB during joining the teacher education program, but possible for students to undergo the changes. Referring to Ernest (1989), MB alteration was able to be done through changes in the level of prospective teachers' thinking, namely self-evaluation by reflecting their experience, beliefs, and knowledge and then make changes by improving knowledge and practices so that conflict of beliefs arose in students. Arising conflict of beliefs may have changed their MB.

\section{Conclusion and Recommendation}

\section{Conclusion}

MKT played an important role in providing prospective teacher students with the mastery of MCK and MPCK. Students with a good procedural knowledge were better at developing conceptual knowledge in higher education. However, prospective teachers not only mastered MKT but also identified MB they had because their MB influenced how prospective teachers viewed on mathematics, learning and teaching mathematics. This study found that the results MKT on 
prospective teachers were not influenced by educational background of parents, material support, social relationship, and GPA. MKT results were influenced by communication with parents regarding expectations to study in the teacher education program.

The beliefs the prospective teacher students had were influenced by the background of high school education. Students with a background in vocational schools and Social Science had a constructivist MB. The beliefs was achieved from experience in applying mathematics in engineering workshop and performing accounting calculation. Students thought that Mathematics was dynamic and useful in many areas. It was strengthened by procedural arithmetic they had. Different from students having Senior High School background and good at procedural arithmetic to change MB, they needed more time.

\section{Suggestion}

This study examined factors affecting MKT and MB. Limitations of variables on these factors required further research about the prospective teacher students' experience during their interaction with Mathematics and review on the communication that occurred with parents so that it could be identified experience which should have been given to students in the teacher education program that could change their MKT and MB. In addition, it could be seen, though the educational background of parents without mastering Mathematics, what type of parent-child communication could support prospective teachers' MKT and MB.

\section{Disclosure statement}

No potential conflict of interest was reported by the authors.

\section{References}

Ambrose, R. (2004). Initiating Change in Prospective Primary School Teachers' Orientations to Mathematics Teaching by Building on Beliefs. Journal of Mathematics Teacher Education, 7, pp.91-119.

Arikunto, S. (2005). Dasar-DasarEvaluasiPendidikan. Jakarta: Bumi Aksara.

Ball, D. (1990). The Mathematical Understandings that Prospective Teachers bring to Teacher Education. Primary School Journal, 90, pp. 449-466.

Ball, D. (2000). Bridging Practices: Intertwining Content and Pedagogy in Teaching and Learning to Teach. Journal of Teacher Education, 51 (3), pp. 241-247.

Ball, D., \& Bass, H. (2009). With an Eye on the Mathematics Horizon: Knowing Mathematics for Teaching to Learners' Mathematics Futures. Paper is Based on a Keynote Address at The $43^{r d}$ Jahrestagung für Didaktik der Mathematik Held in Oldenburg, Germany, March 1 - 4, 2009.

Ball, D., Hill, H. C., \& Bass, H. (2005). Knowing Mathematics for Teaching: Who Knows Mathematics Well Enough to Teach Third Grade, and How Can We Decide? Journal of the American Federation of Teachers, pp. 14-22.

Ball, D., Thames, M., \& Phelps, G. (2008). Content Knowledge for Teaching What Makes It Special? Journal of Teacher Education, 59 (5), pp. 389-407. 
Bicer, A., Capraro, M., Capraro, R. (2013) The Effects of Parents' SES and Education Level on Students' Mathematics Achievement: Examining the Mediation Effects of Parental Expectations and Parental Communication. The Online Journal of New Horizon in Education, Vol 3, Issue 4.

Bornstein, M. H., \& Bradley, R., H. (2003). Socioeconomic Status, Parenting, and Child Development. New Jersey: Lawrence Erlbaum Associates, Inc.

Brakoniecki, A. (2009). Mathematics Knowledge For Teaching Exhibited By Preservice Teachers Responding To Mathematics And Pedagogical Contexts. Swars, S. L., Stinson, D. W., \& Lemons-Smith, S. (Eds.). Proceedings of the $31^{\text {st }}$ annual meeting of the North American Chapter of the International Group for the Psychology of Mathematics Education. Atlanta, GA: Georgia State University.

Cheang W. K., Yeo K. J., Chan C. , Lim-Teo S. K., Chua K. G., \& Ng L. E. (2007). Development of Mathematics Pedagogical Content Knowledge in Student Teachers. The Mathematics Educator, 10 (2), pp. 27-54.

Choo, T.L., \& Darling-Hammond, L. (2011). Creating Effective Teachers and Leaders in Singapore In Linda Darling-Hammond and Robert Rothman, eds., Teacher and Leader Effectiveness in HighPerforming Education Systems. Washington, DC: Alliance for Excellent Education and Stanford, CA: Stanford Center for Opportunity Policy in Education

Corcoran, T. (1995). Helping Teachers Teach Well: Transforming Professional Development. CPRE Policy Briefs. RB-16 June 1995.

Demir, I., Kilic, S., \& Unal, H. (2010). Effects of Students' and Schools' Characteristics on Mathematics Achievement: Findings from PISA 2006, Procedia social and Behavioral Science, 2, pp. 3099-3103.

Ernest. (1989). Impact of Beliefs on the Teaching of Mathematics', in P. Ernest, Ed. Mathematics Teaching: The State of the Art, London: Falmer Press, pp. 249254 .

Eynde, P., Corte, E., \& Verschaffel, L. (2002). Framing Students' Mathematics-Related Beliefs.Leder, G., Pehkonen, E., Törner, G. (Eds.), Beliefs: A Hidden Variable in Mathematics Education?(pp.13-37). Dordrecht, The Netherlands: Kluwer Academic Publishers.

Goldrick-Rab, S., Harris, D., \&Trostel, P. (2009). Why Financial Aid Matters (or Does Not) for College Success: Toward a New Interdisciplinary Perspective. In Higher Education: Handbook of Theory and Research, Smart, J. (Editor), Springer, Volume 24.

Guo, G., \& Harris, K. M. (2000) The Mechanism Mediating the Effects of Poverty on Children's Intellectual Development, Demography, 37, pp. 431-447.

Hill, H.C,, Ball, D.L., \& Schilling, S.G. (2008). Unpacking Pedagogical Content Knowledge: Conceptualizing and Measuring Teachers' Topic-Specific Knowledge of Students. Journal for Research in Mathematics Education, 39 (4), pp. 372-400.

Leder, G., Pehkonen, E., \& Törner, G. (2002). Beliefs: A Hidden Variable in Mathematics Education? Dordrecht, The Netherlands: Kluwer Academic Publishers.

Luft, J., \& Roehirg, G. (2007). Capturing Science Teachers' Epistemological Beliefss: The Development of the Teacher Beliefs Interview. Electronic Journal of Science Education, 11 (2), pp. 38-63.

Ma, L. (1999). Knowing and teaching Primary mathematics: Teachers' understanding of fundamental mathematics in China and the United States. Mahwah, N.J: Lawrence Erlbaum Associates.

McLeod, D. (1992). Research on Affect in Mathematics Education: a Reconceptualization. In D. Grouws (Ed.), Handbook of Research on Mathematics Teaching and Learning. New York: MacMillan Publishing Company. 
McLeod, D., B., \& McLeod, S., H. (2002). Synthesis - Beliefs and Mathematics Education: Implications for Learning, Teaching, and Research. In Leder, G., Pehkonen, E., Törner, G. Beliefss: A Hidden Variable in Mathematics Education? Kluwer Academic Publishers.

Mosvold, R., \&Fauskanger, J. (2013).Teachers' Beliefs about Mathematical Knowledge for Teaching Definitions. International Electronic Journal of Mathematics Education, 8 (2), pp. 43-61.

Mushtaq, I., Khan, S.N. (2012). Factors Affecting Students' Academic Performance.Global Journal of Management and Business Research, 12 (9), pp. 17-22.

Noble, J., Roberts, L., \& Sawyer, L. (2006). Student Achievement, Behavior, Perceptions, and other Factors Affecting ACT Scores. ACT Research Report Series 2006 - 1. http://www.act.org/research/researchers/reports/pdf/ ACT_RR2006-1.pdf (20 Juni 2015).

Northcote, M. (2009). Educational Beliefs of Higher Education Teachers and Students: Implications for Teacher Education. Australian Journal of Teacher Education, 34 (3), pp. 69-81.

Novikasari, I. (2013). Analisis Kompetensi Matematika Kelas IV di dalam Kurikulum 2013. MakalahDiseminarkan di P4TK Yogyakarta, November 2013.

Okioga, C., K. (2013). The Impact of Students' Socio-economic Background on Academic Performance in Universities, a Case of Students in Kisii University College.American International Journal of Social Science, Vol.2 (2), pp. 38-46.

Petrou, M., \&Goulding, M. 2011. Conceptualizing Teachers' Mathematical Knowledge in Teaching. In Rowland, T \& Ruthven, K (Ed.), Mathematical Knowledge in Teaching. www.springer.com (15 November 2014).

Philipp, R. A. (2007). Mathematics teachers' beliefs and affect. In F. K. Lester (Ed.), Second handbook of research on mathematics teaching and learning (pp. 257-315). United States: Information Age Publishing.

Powell, A. ,\& Hanna, E. (2006). Understanding Teachers' Mathematics Knowledge for Teaching: A Theoretical and Methodological Approach. Proceedings 30th Conference of the International Group for the Psychology of Mathematics Education, 4, pp. 369-376.

Raymond, A. (1997). Inconsistency between a beginning Primary teacher's mathematics beliefs and practice.Journal for Research in Mathematics Education, 28(5), 555-576

Schmidt, W., \& Kennedy, M. (1990). Teachers' and Teacher Candidates' Beliefs About Subject Matter and about Teaching Responsibilities. Michigan: The National Center for Research on Teacher Education.

Schoenfeld, A. H., \& Kilpatrick, J. (2008). Toward a Theory of Proficiency in Teaching Mathematics. In D. Tirosh\& T. Wood (Eds.), The international handbook of mathematics teacher education: Tools and processes in mathematics teacher education. Rotterdam: Sense Publishers.

Shalberg, Pasi. (2011). Developing Effective Teachers and School Leaders: The Case of Finland In Linda Darling-Hammond and Robert Rothman, eds., Teacher and Leader Effectiveness in HighPerforming Education Systems. Washington, DC: Alliance for Excellent Education and Stanford, CA: Stanford Center for Opportunity Policy in Education

Somayajulu, R. B. (2012). Building Pre-Service Teacher's Mathematical Knowledge for Teaching of High School Geometry. Dissertation: The Ohio State University.

Starkey, P., \& Klein, A. (2000). Fostering Parental for Children's Mathematical Development. Early Education \& Development, 11 (5), pp. 659-680

Sudjana.(2005). Penilaian Hasil Proses BelajarMengajar.Bandung: Rosdakarya.

Tatto, M. T., Schwille, J., Senk, S., Ingvarson, L., Peck, R., \& Rowley, G. (2008). Teacher Education and Development Study in Mathematics (TEDS-M): Policy, practice, and readiness to teach primary and secondary mathematics. Conceptual framework. East Lansing, MI: Teacher Education and Development International Study Center, College of Education, Michigan State University. 
Topkaya, E.Z., Uztosun, M., S. (2012). Choosing Teaching as a Career: Motivations of Pre-service English Teachers in Turkey. Journal of Language Teaching and Research, 3 (1), pp. 126-134.

Törner, G., \& Pehkonen, E. (1999). Teachers`Beliefs on Mathematics Teaching-comparing different self-estimation methods a case study. http://www.uni-duisburg.de/FB11/PROJECTS/MAVI.html (20February 2014).

Wayt, 1. (2012). The Impact of Students' Academic and Social Relationships on College Student Persistence. Thesis: University of Nebraska.

Welder, R., \&Simonsen, L. (2011). Primary teachers' mathematics knowledge for teaching prerequisite algebra concepts.IUMPST: The Journal. Vol 1, January, 2011.

Zerpa, C., Kajander, A., Van Barneveld, C. (2009). Factors That Impact Preservice Teachers' Growth In Conceptual Mathematical Knowledge During A Mathematics Methods Course. International Electronic Journal of Mathematics Education, Vol.4, No.2, pp. 57-76. 